\title{
DELIMITATION OF AREAS OF ENVIRONMENTAL CONFLICTS ON THE BACKGROUND OF GEOLOGICAL CONDITIONS, EXEMPLIFIED BY STARY SĄCZ COMMUNE
}

\author{
Slávka GAŁAŚ ${ }^{1}$ \\ AGH University of Science and Technology in Krakow \\ Faculty of Geology, Geophysics and Environmental Protection
}

\begin{abstract}
Delimitation and characterization of areas of conflict are essential to assess suitability of land for different activities carried out in the field of rational land use. In the paper, delimitation of the conflict areas and conflicts categorization in terms of possibility of their overcoming, the scale of the range and the period of their occurrence exemplified by urban - rural commune Stary Sącz have been presented. The software ArcGIS 10.1, the method of maps superimposing and analysis of interactions between different geoenvironmental factors have been applied to obtain the goal of the investigation. Specific geological structure together with morphological and climatic conditions in Stary Sącz commune create ideal conditions for occurrence of con-flict areas on the background of the geological conditions. Accurate and early recognition of these conflicts - existing and potential ones, is a prerequisite for the environmental risk prevention and elimination of its effects through the proper preparation of planning documents and development plans and programs.
\end{abstract}

Keywords: delimitation, geological conditions, areas of environmental conflicts

Corresponding author: Slávka Gałaś, AGH University of Science and Technology, Faculty of Geology, Geophysics and Environmental Protection, Department of Environmental Analysis, Cartography and Economic Geology, Al. Mickiewicza 30, 30-059 Krakow, Poland, e-mail:sgalas@geol.agh.edu.pl, tel. +48126172383 


\section{INTRODUCTION}

Issues of environmental conflicts, delimitation of areas of their occurrence and their detailed analysis are now frequently discussed when activities related to planning spatial development and protection of the environment are carried out $[20,6,7,4]$. Accurate and early recognition of these conflicts - existing and potential ones, is a prerequisite for preventing the environmental risk and elimination of its impact through proper preparation of planning documents, development plans and programs.

Geological conditions are essential for development and spatial use of land due to various factors related to the relief, nature and origin of the land, geological conditions, potential mineral resources, underground water, geotouristic potential and occurrence of geohazards. On the basis of valuation of the geological conditions regarding possible land use, areas of environmental conflicts, their scale and nature can be delimited. Identification of such areas and their characteristics provide opportunities for rational land development of the area.

\section{CHARACTERISTICS OF THE AREA RESEARCH}

Urban - rural commune Stary Sącz is located in the southern part of Małopolska voivodeship, at the confluence of two major rivers the Dunajec and the Poprad. It has a population of 22,465 inhabitants and it covers the area of $102.4 \mathrm{~km}^{2}$ [5]. The commune is situated in the Beskid Mountains and from the economic point of view it can be defined as agricultural - forest one, as $86 \%$ of the area is covered by farmlands and forests. The rest of the area is occupied by other lands and wastelands. The whole area of the commune is the area of wildlife conservation, $25.9 \%$ of the commune belongs to the Poprad Landscape Park (PKK), whose boundaries coincide with the boundaries of the Natura 2000 "Poprad Refuge", the buffer zone of the landscape park occupies $71.3 \%$ of the commune and its large part coincides with the Area of Southern Małopolska Protected Landscape [5].

Mountainous character of the community, poor soil, protective functions of forests and limitations resulting from regulations of different forms of wildlife conservation cause that development of tourism and recreation has been taken as the main direction of economic and social development of the community [21].

\section{RESEARCH METHODOLOGY}

The methodology of delimitation of the environmental conflicts arising from geological conditions of the commune included analysis, synthesis and 
evaluation of geological conditions of the commune on the basis of available archival sources, among them: Detailed Geological Map of Poland, Geoenvironmental Map of Poland, Hydrogeological Map of Poland, Hydrographic Map of Poland at the scale of 1:50 000, sheet Nowy Sącz with explanations $[16,17,2,3,1]$. Information about the subject of the study was supplemented by data from online databases provided by the Polish Geological Institute - National Research Institute, the Polish Hydrological Institute, Geoportal web portal, the web service Małopolska Infrastructure Spatial Data, as well as flood risk maps available from the National Water Management web site.

The method of map overlapping together with analysis of correlation of geoenvironmental factors has been applied to delimit the conflict areas. The following criteria have been taken into consideration in this process [18]:

- resources/values which can be applied to fulfil various functions and needs,

- facilities/activities (including planned investments), negatively affecting the quality of the individual components of the environment (water, air, soil, forests, fauna, flora and human health), and the areas and places legally protected,

- areas of geohazards occurrence.

Categorisation according to Przewoźniak [20] has been carried out for the determined areas of environmental conflicts. The categorization divides the conflicts in land development into two main categories: anthropocentric and biocentric. The anthropocentric conflicts as conflicts about human life have been divided into the following ones due to the subject [20]:

- resource ones, concerning usage of environmental resources,

- sozological, regarding environmental nuisance,

- functional ones, due to the usage of the space for various socio - economic functions,

- risk ones, related to human environment hazards caused by natural processes.

Biocentric conflicts are conflicts about the conservation of nature and its resources, which have been divided into the following conflicts [20]:

- devalorization, concerning physical damages in nature and natural resources,

- functional, concerning usage of nature,

- conservative, related to protection of nature.

Then the identified conflicts have been divided according to possibility of their resolving into: relative barriers - those that should not or cannot be resolved and absolute ones - which resolving is associated with the financial issue. The conflicts have been further divided in terms of spatial development and planning 
documentation into the existing and potential ones in relation to the time of their occurrence.

\section{RESULTS}

As far as the geological structure of the area is concerned the whole area of the community is located within the largest tectonic unit of the Outer Carpathians Magura Nappe. The north-west part of the community is situated in the Kotlina Sądecka Basin. Sedimentation of alternating layers of sandstone and shale, enriched with mudstone intercalations, conglomerates, claystone, marl and limestone led to formation of a complex of rocks called the Carpathian flysch, which is characterized by a variable resistance of rocks to denudation processes, predisposition to initiate morphodynamic phenomena, varied permeability of the bed and its decreased retainability [16, 17]. The mentioned features of the ground are essential for spatial development in the community, as they determine possibility and limitations of the spatial development planning.

The specific geological structure together with unfavourable morphological and climatic conditions in the commune differentiate intensity of denudation processes of soil erosion, especially ablation and downhill creep and they favour initiation of landslide phenomena (Fig. 1). As a part of spatial analysis, a map of slopes inclination has been prepared by means of the program ArcGIS 10.1, basing on a digital terrain model (DTM) with spatial resolution of 10 metres. Then the analysed area has been divided into slope inclination classes according to the susceptibility of slopes to land-sliding (from the lowest to the highest): above $20^{\circ}, 0-9^{\circ}, 9-15^{\circ}, 9-15^{\circ}$ (classification after Zabuski, Thiel, Bober, 1999) [24]. Only areas of the largest and high susceptibility which, as it can be seen, occupy a large part of the community area of landslide and erosion areas have been marked on the Map of areas of environmental conflicts in Stary Sacz community (Fig. 1). Most of the existing landslides in the commune belong to the dormant category, but since 1997 the intensity of the landslide phenomena has been rising in the investigated area. In July 2010, after heavy rain several landslides were activated.

The commune is located in the drainage basin of the Dunajec, one of the major tributaries of the Vistula river. According to the analysis of the maps of areas endangered by flooding in Małopolska voivodeship and the maps where flooding is likely to occur, the flood areas where high risk of flooding occurs [10] have been marked on the Map of the areas of environmental conflict in Stary Sącz commune (Fig. 1). During the flood in 2010, a railway bridge between Nowy Sącz and Stary Sącz over the Poprad River was destroyed. 
The described area due to significant hydrological resources has been classified as the Carpathian Spring - Supply Zone, where surface and underground water should be the subject of quantitative and qualitative protection [9]. The commune is located within three Major Underground Water Reservoirs (GZWP) [8]: GZWP 438 Magura - Nowy Sącz, GZWP 439 Magura - Gorce and GZWP 437 Dunajec River Valley. The area of GZWP 437 is connected with Quaternary alluvial deposits and due to infiltration charging of the major part of the reservoir its area is covered by the highest water protection which means high sanitary regime in the neighbouring areas $[1,3,2,19]$. The areas have been taken into consideration during assessment of environmental risks and locations of the areas of high and very high risk of hazard to the main level of the aquifer have been marked on the Map of areas of environmental conflictin Stary Sącz commune (Fig. 1).

Minerals are non-renewable resources, except of underground water resources, including thermal ones. Therefore, improper management of the surface over resource deposits can cause irreversible loss of the mineral resources, which may in the future result in the lack of raw materials. There are eight documented mineral deposits of the following types: road and building stones, clays for bricks and tiles, natural aggregates, there are also areas of their perspective and predicted occurrence in the area of the analysed commune [28]. The areas have been marked on the Map of areas of environmental conflict in Stary Sącz commune (Fig. 1) as the areas of potential exploitation of mineral resources and the areas of current exploitation of minerals.

Analysing the current state of the mineral resources base in the area of Stary Sącz commune and records in planning documents of the commune such as the Study of Conditions and Directions of Spatial Management (SUiKZP) and the Local Plan of Spatial Development (MPZP) [22, 23, 11, 12, 13, 14], unsatisfactory changes in protection of deposit resources can be observed, especially due to designation of the areas of their occurrence for such economic purposes which restrain access to those resources. Such situation has occurred in case of deposits of high-quality natural aggregate "Stary Sacz - Moszczenica field $A^{\prime \prime}$ [15], where the area of its occurrence covering the area of 53.68 hectares has been allocated for an airport or an airfield and the deposit "Podmajerz" which surface area equal to 61.10 ha has been reduced by 10.75 ha due to the road construction and changes in land use over the deposit $[22,23$, $11,12,13,14]$. These investments are supposed to increase tourist attractiveness and communication accessibility of the study area, but on the other hand, they may have a negative impact on the quality of the environment and the rational use of the environmental resources and their protection. This fact is inconsistent with the valid law: Art. 10, 15 of Spatial Planning and Development Act of 2003 
[25], Art. 95 Geological and Mining Law of 2011[26] and the Art. 125 of the Act of 27 April 2001 Environmental Law [27] which imposes the obligation to include in the Study of Conditions and Directions of Spatial Management (SUiKZP) and the Local Development Plan (MPZP) occurrence of documented mineral deposits and obligatory specification in MPZP of the borders and ways of managing the lands or objects to be protected which are determined on the basis of separate regulations with the aim to protect mineral resources deposits and to ensure possibility of their complex usage as the natural wealth of the country.

Characteristics of particular conflicts in terms of different categories have been made basing on the analysis and evaluation of geological conditions and the delimitation of areas of environmental conflicts (Fig. 1, Table 1).

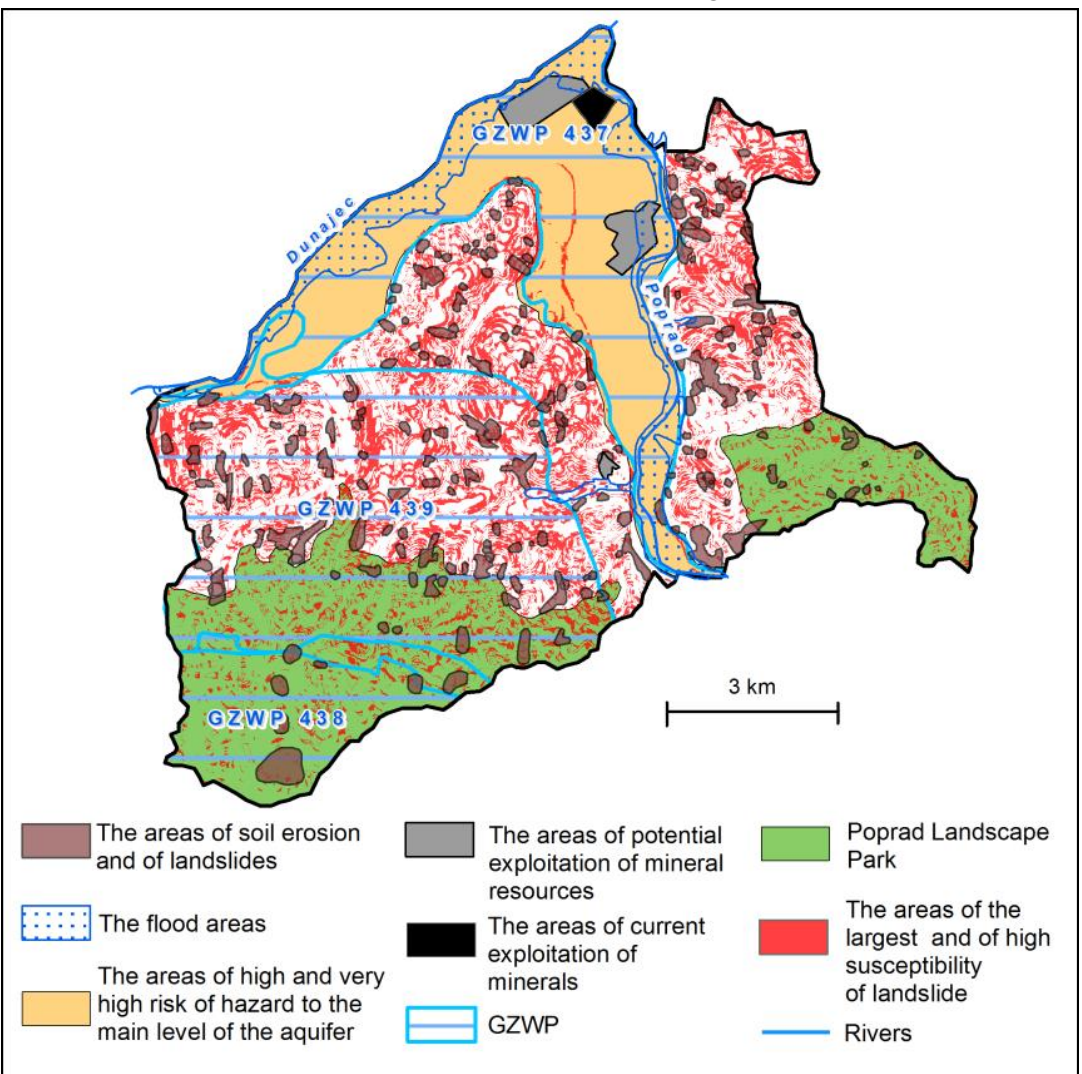

Fig. 1. Map of areas of environmental conflicts against the background of geological conditions in Stary Sącz commune

Anthropocentric conflicts associated with the hazard to the human environment through natural processes have the largest range. Biocentric conflicts concern 
devalorization conflicts and usage conflicts. The identified conflicts represent barriers to development of Stary Sącz community. The conflicts which should or cannot be settled are determined as relative barriers. In case of the analysed area they are mainly the areas of occurrence of mineral resources that should be protected against designating them in spatial planning for the purposes which will restrain future access to them. The absolute barrier, but also local ones, are the conflicts associated with the occurrence of geohazards. Formation of areas which are endangered by erosion, landslides and may be flooded can be decreased if appropriate spatial management and technical solutions are applied. However, such tasks are associated with high financial outlays.

Table 1. Areas of conflicts against the background of the geological conditions and the characteristics of environmental conflicts in Stary Sącz commune

\begin{tabular}{|c|c|c|c|c|c|c|}
\hline \multirow{3}{*}{$\begin{array}{l}\text { Areas of environmental } \\
\text { conflicts against the } \\
\text { background of the } \\
\text { geological conditions }\end{array}$} & \multicolumn{6}{|c|}{ The characteristics of environmental conflicts } \\
\hline & \multicolumn{2}{|c|}{ according by subject } & \multicolumn{2}{|c|}{$\begin{array}{l}\text { according to } \\
\text { possibility of } \\
\text { their } \\
\text { resolving }\end{array}$} & \multicolumn{2}{|c|}{$\begin{array}{l}\text { according } \\
\text { to the time } \\
\text { of their } \\
\text { occurrence }\end{array}$} \\
\hline & 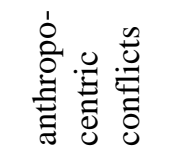 & 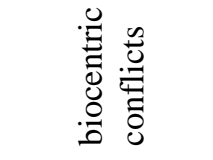 & 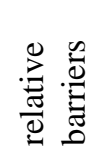 & 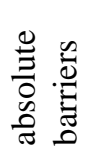 & 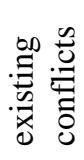 & 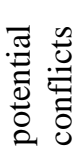 \\
\hline $\begin{array}{l}\text { The areas of soil erosion } \\
\text { and of landslides }\end{array}$ & risk & - & - & $\mathbf{X}$ & $\mathbf{X}$ & $\mathbf{X}$ \\
\hline The flood areas & risk & - & - & $\mathbf{X}$ & $\mathbf{X}$ & $\mathbf{X}$ \\
\hline $\begin{array}{l}\text { The areas of high and } \\
\text { very high risk of hazard } \\
\text { to the main level of the } \\
\text { aquifer }\end{array}$ & sozological & $\begin{array}{l}\text { devalorization } \\
\text { functional }\end{array}$ & $\mathbf{X}$ & - & $\mathbf{X}$ & $\mathbf{X}$ \\
\hline $\begin{array}{l}\text { The areas of potential } \\
\text { exploitation of mineral } \\
\text { resources }\end{array}$ & $\begin{array}{c}\text { resource } \\
\text { functional } \\
\text { sozological } \\
\end{array}$ & $\begin{array}{l}\text { devalorization } \\
\text { functional }\end{array}$ & $\mathbf{X}$ & - & - & $\mathbf{X}$ \\
\hline $\begin{array}{l}\text { The areas of current } \\
\text { exploitation of minerals }\end{array}$ & $\begin{array}{c}\text { resource } \\
\text { functional } \\
\text { sozological }\end{array}$ & $\begin{array}{l}\text { devalorization } \\
\text { functional }\end{array}$ & $\mathbf{X}$ & - & $\mathbf{X}$ & - \\
\hline $\begin{array}{l}\text { The areas of the largest } \\
\text { and of high } \\
\text { susceptibility of } \\
\text { landslide }\end{array}$ & risk & - & - & $\mathbf{X}$ & $\mathbf{X}$ & $\mathbf{X}$ \\
\hline
\end{tabular}




\section{CONCLUSIONS}

Delimitation and characteristics of conflict areas are essential to assess the suitability of land for different activities carried out in the field of rational land use. Spatial land management tends from the practical aspect to the rational space management, taking into account existing and future needs of society. Varied land and geological formation, location of Stary Sącz community within the protected areas and plans aiming at development of tourism cause that spatial conflicts become especially evident in the area of the commune. Basing on the method of delimitation and assessment of the environmental conflicts in Stary Sacz commune it can be stated that in most cases, the source of this conflict is the occurrence of geohazards and competition to get access to natural resources that are useful for various socio-economic functions related to different forms of nature, landscape and natural resources protection. It is essential for spatial planning to understand potential areas of conflicts as it allows to carry on activities which prevent possible environmental risks and reduce the existing ones by proper preparation of planning and development documents. Early detection of conflicts and their range will help to make correct decisions about rational development, in order to meet interest of various groups.

\section{ACKNOWLEDGMENT}

The study was supported by the National Science Centre on the basis of the decision no. DEC-2011/03/B/HS4/03933.

\section{REFERENCES}

1. Baścik M., Siwek J., Trafas K.: Komentarz do Mapy Hydrograficznej w skali 1:50 000. Arkusz M-34-90-A Nowy Sącz, GUGiK Główny Geodeta Kraju, GEPOL, Poznań 2004.

2. Bojakowska I., Stec B.: Mapa Geośrodowiskowa Polski - plansza A, arkusz Nowy Sacz w skali 1:50 000 wraz z objaśnieniem, PIG, Warszawa 2004.

3. Chowaniec J., Witek K.: Mapa hydrogeologiczna Polski w skali 1:50 000 wraz z Objaśnieniem, ark. Nowy Sacz. Centr. Arch. Geol. Państw. Inst. Geol. Warszawa 1997.

4. Dutkowski M.: Konflikty $w$ gospodarowaniu dobrami środowiskowymi, Wyd. UG, Gdańsk 1995.

5. GUS: Bank danych lokalnych, www.stat.gov.pl, 2013. 
6. Kistowski M.: Kolizje $i$ konflikty środowiskowe $w$ planowaniu przestrzennym na obszarach cennych przyrodniczo, Czasopismo Techniczne, z7-A/2007.

7. Kistowski M.: Problemy lokalizowania inwestycji na terenach cennych przyrodniczo (w:) Ochrona przyrody, praca zbior. pod red. M. Gwiazdowicza, Studia Biura Analiz Sejmowych Kancelarii Sejmu, Tom 10, Wydawnictwo Sejmowe Kancelarii Sejmu, Warszawa, 2008, s. 139-163.

8. Kleczkowski A.S.: Mapa głównych zbiorników wód podziemnych (GZWP) w Polsce wymagajacych szczególnej ochrony. Inst. HiGI AGH Kraków, 1990.

9. Mapa obszarów narażonych na niebezpieczeństwo powodzi dla woj. małopolskiego, Mapa obszarów, na których wystapienie powodzi jest prawdopodobne $w$ woj. matopolskim, 2013,

http://www.kzgw.gov.pl/pl/Wstepna-ocena-ryzyka-powodziowego.html

10. Macek, J.: Opracowania ekofizjograficzne dla potrzeb Miejscowego planu zagospodarowania przestrzennego Barcice, Nowy Sącz 2006.

11. Miejscowy plan zagospodarowania przestrzennego miasto Stary Sacz, PLAN NR 1. Uchwała Nr XXX/323/04 Rady Miejskiej w Starym Sączu $\mathrm{z}$ dnia 30 grudnia $2004 \mathrm{r}$.

12. Zmiana Miejscowego planu zagospodarowania przestrzennego miasto Stary Sacz, PLAN NR 1. Uchwała Nr XL/507/09 Rady Miejskiej w Starym Sączu $\mathrm{z}$ dnia 18 maja $2009 \mathrm{r}$.

13. Miejscowy plan zagospodarowania przestrzennego miasto Stary Sacz, PLAN NR 2. Uchwała Nr XXX/324/04 Rady Miejskiej w Starym Sączu $\mathrm{z}$ dnia 30 grudnia $2004 \mathrm{r}$.

14. Zmiana Miejscowego planu zagospodarowania przestrzennego miasto Stary Sacz, PLAN NR 2. Uchwała Nr XXXVII / 490 / 09 Rady Miejskiej w Starym Sączu z dnia 30 marca $2009 \mathrm{r}$.

15. Nieć M., Stryszewski M. (red.), Uberman R.: Programowanie eksploatacji $i$ zagospodarowania terenów pogórniczych złóż kruszywa naturalnego $w$ dolinach rzek karpackich na przykładzie Karpat Zachodnich. Monografia, Ucz. Wyd. Nauk.-Dyd. AGH, Kraków 2006.

16. Oszczypko N., Wójcik A.: Szczegółowa Mapa Geologiczna Polski w skali 1:50 000, arkusz Nowy Sacz, Polska Agencja Ekolog. SA., Warszawa1989.

17. Oszczypko N., Wójcik A.: Objaśnienie do Szczegółowej Mapy Geologicznej Polski w skali 1:50 000, arkusz Nowy Sacz, PIG, Warszawa1993.

18. Pietrzak A.: Planowanie przestrzenne w obszarach chronionych gminy Stary Sacz, praca dyplomowa, Kraków. 2010.

19. Program Ochrony Środowiska dla Miasta i Gminy Stary Sącz (na lata 2004 - 2011 wraz z prognoza do roku 2015), Nowy Sącz. 
20. Przewoźniak M.: Konflikty w zagospodarowaniu przestrzennym bałtyckiego obszaru przybrzeżnego w Polsce [w] Zintegrowane zarządzanie obszarami przybrzeżnymi w Polsce - stan obecny i perspektywy. Część 3: Morze - ląd. Wzajemne relacje. Praca zbior. pod red. K. Furmańczyka, Uniwersytet Szczeciński, Instytut Nauk o Ziemi, 2008, s. 29-43.

21. Strategia Rozwoju Gminy Stary Sacz na lata 2013-2020, www.stary.sacz.pl

22. Studium Uwarunkowań i Kierunków Zagospodarowania Przestrzennego Miasta i Gminy Stary Sacz. Uchwała Nr XXVIII/73/2000 Rady Miejskiej w Starym Sączu z dnia 11 września 2000 r.

23. Zmiana Studium Uwarunkowań $i$ Kierunków Zagospodarowania Przestrzennego Miasta i Gminy Stary Sacz. Uchwała Nr XXVI/328/08 Rady Miejskiej w Starym Sączu z dnia 28 lipca 2008 r.

24. Zabuski L., Thiel K.., Bober L.: Osuwiska we fliszu Karpat polskich. Geologia - modelowanie - obliczanie stateczności. Instytut Budownictwa Wodnego PAN, 1999.

25. Ustawa $z$ dnia 27 marca 2003 r. o planowaniu $i$ zagospodarowaniu przestrzennym

26. Ustawa z dnia 9 czerwca 2011 r. Prawo geologiczne i górnicze

27. Ustawa z dnia 27 kwietnia 2001 r. Prawo ochrony środowiska

28. www.geoportal.pgi.gov.pl/midas-web System Gospodarki $i$ Ochrony Bogactw Mineralnych MIDAS, 2013.

\section{DELIMITACJA OBSZARÓW KONFLIKTÓW ŚRODOWISKOWYCH NA TLE UWARUNKOWAN GEOLOGICZNYCH NA PRZYKŁADZIE GMINY STARY SĄCZ}

\section{Streszczenie}

Delimitacja oraz charakterystyka obszarów konfliktowych jest podstawą dokonania oceny przydatności terenów pod różne rodzaje działalności w ramach racjonalnie prowadzonej gospodarki przestrzennej. W pracy dokonano delimitację obszarów konfliktowych oraz kategoryzację konfliktów pod względem możliwości ich pokonania, skały zasięgu oraz czasu ich występowania na przykładzie gminy miejsko - wiejskiej Stary Sącz. Do tego celu zastosowano oprogramowanie ArcGis 10.1 oraz metodę nakładania map i analizę współzależności pomiędzy poszczególnymi czynnikami geośrodowiskowymi. Specyficzna budowa geologiczna w połączeniu z niekorzystnymi warunkami morfologicznymi oraz klimatycznymi gminy Stary Sącz stwarza idealne warunki na występowanie obszarów konfliktów na tle uwarunkowań geologicznych. $\mathrm{Na}$ podstawie zastosowanej metody delimitacji oraz oceny konfliktów środowiskowych gminy Stary Sącz można stwierdzić, że w większości przypadków źródłem tych 
konfliktów jest występowanie geozagrożeń oraz konkurencja o dostęp do zasobów środowiska, przydatnych dla różnych funkcji społeczno-gospodarczych w stosunku do różnych form ochrony przyrody, krajobrazu oraz zasobów naturalnych. Dokładne i wczesne poznanie tych konfliktów - istniejących oraz potencjalnych, jest warunkiem zapobiegania ryzyku środowiskowemu oraz eliminacji jego skutków poprzez prawidłowe przygotowanie dokumentacji planistycznej oraz planów i programów rozwoju.

Słowa kluczowe: delimitacja, uwarunkowania geologiczne, obszary konfliktów środowiskowych

Editor received the manuscript: 12.05 .2014 